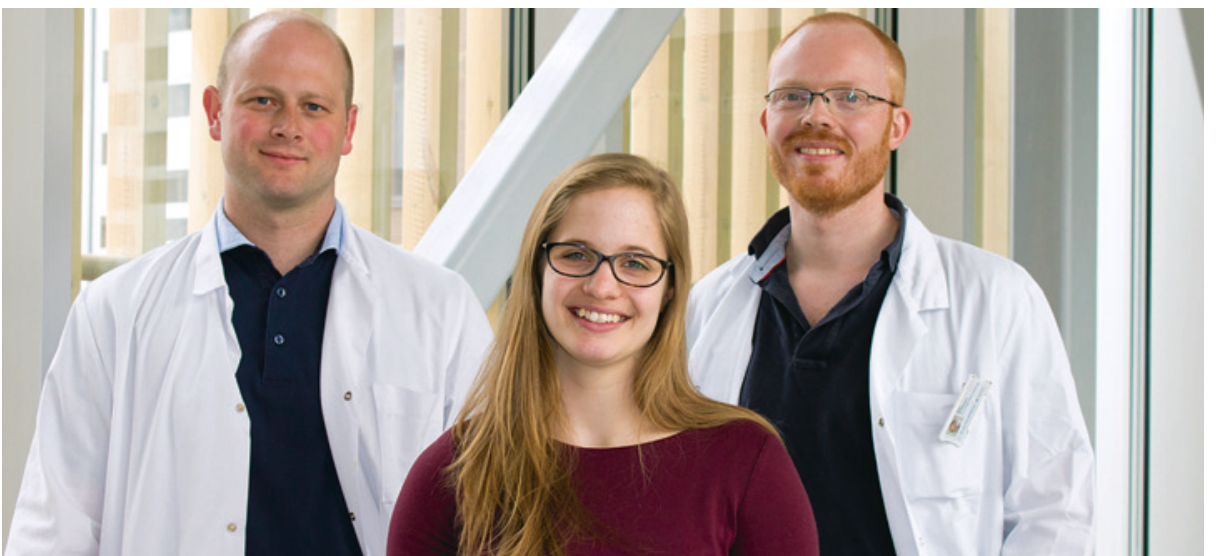

Fra venstre: Erik Magnus Berntsen, Anne Line Stensjøen og Ole Solheim. Foto: Kari Williamson

\title{
Mange glioblastomer vokser raskt før operasjonen
}

Det er stor variasjon i glioblastomers veksthastighet. Enkelte svulster kan bli dobbelt så store i perioden mellom diagnose og operasjon viser en ny norsk studie.

Glioblastomer er ondartede hjernesvulster med dårlig prognose. Kurativ behandling finnes ikke, men de fleste pasientene gjennomgår som regel kirurgisk fjerning av så mye av svulsten som mulig, etterfulgt av stråle- og kjemoterapi. Median overlevelse etter slik behandling er omkring 14 måneder. I en nylig publisert norsk studie har man undersøkt hvor raskt glioblastomer vokser før man kommer i gang med behandlingen og har forsøkt å estimere hva slags vekstkurve denne krefttypen følger (1).

Totalt 106 pasienter som var operert ved Nevrokirurgisk avdeling ved St. Olavs hospital i perioden 2004-14 og som hadde gjennomgått minst to MR-undersøkelser før operasjon med minst 14 dagers mellomrom ble inkludert. Glioblastomet hos disse pasientene ble segmentert ut fra kontrastforsterkede T1-vektede MR-bilder på begge tidspunktene. Svulstvolumene ble brukt til å beregne veksthastigheten i form av spesifikk vekstrate og doblingstid samt til å estimere en vekstkurve for glioblastomer.

Veksthastigheten for glioblastomene varierte mye fra pasient til pasient. Mediansvulsten hadde en daglig vekst på $1,4 \%$, noe som tilsvarer en dobling av volumet omtrent hver 50. dag. Omtrent en tredel av svulstene hadde en dobling eller mer av volumet i den tiden pasienten ventet på operasjon, mens en tredel ikke hadde noen signifikant vekst. I undersøkelsen av vekstkurver ble tre ulike modeller sammenliknet. En såkalt Gompertz-vekstmodell passet best til den observerte veksten.

- Dette er den første store studien der man har sett på vekst av glioblastomer før behandling, sier Anne Line Stensjøen, som er studiens førsteforfatter. - Kunnskap om veksthastighet og vekstmønstre er viktig for å planlegge pasientlogistikken og gir et bedre beslutningsgrunnlag for utarbeiding av såkalte pakkeforløp. Tidligere studier har vist at økt reseksjonsgrad under operasjonen fører til lengre overlevelse for pasientene. De raske veksthastighetene vi fant $i$ vår studie, viser behovet for å gjøre tiden mellom diagnosetidspunkt og operasjon så kort som mulig for å unngå at svulsten blir unødvendig stor og dermed vanskeligere å fjerne, sier hun.

\section{Forskerlinjestudent}

Anne Line Stensjøen er forskerlinjestudent ved Det medisinske fakultet, Norges teknisknaturvitenskapelige universitet. Dette er hennes første publiserte artikkel. Hovedveileder er Erik Magnus Berntsen, lege i spesialisering i radiologi ved St. Olavs hospital og førsteamanuensis. Biveiledere har vært Ole Solheim og Asta Håberg. Studien har vært et samarbeid mellom Nasjonal kompetansetjeneste for funksjonell MR, Nasjonal kompetansetjeneste for ultralyd og bildeveiledet behandling og Avdeling for radiologi og Nevrokirurgisk avdeling ved St. Olavs hospital.

\section{Lise Mørkved Helsingen}

Tidsskriftet

\section{Litteratur}

1. Stensjøen AL, Solheim O, Kvistad KA et al. Growth dynamics of untreated glioblastomas in vivo. Neuro-oncol 2015. E-publisert 10.3.
Ordforklaringer

Segmentering: Brukes her om det å dele opp et radiologisk bilde i ulike regioner, for eksempel for å skille svulstvev fra normalt vev, slik at man ved hjelp av en programvare kan regne ut volumet av de ulike regionene.

Spesifikk vekstrate: Prosentvis vekst per dag, regnet ut fra volumet på to tidspunkter og tidsintervallet mellom disse tidspunktene.

Gompertz-vekst: Logistisk vekstmodell der svulsten starter med eksponentiell vekst før doblingstiden blir lengre etter hvert som næringstilgangen blir dårligere. Til slutt vil svulstveksten nærme seg en platåfase.

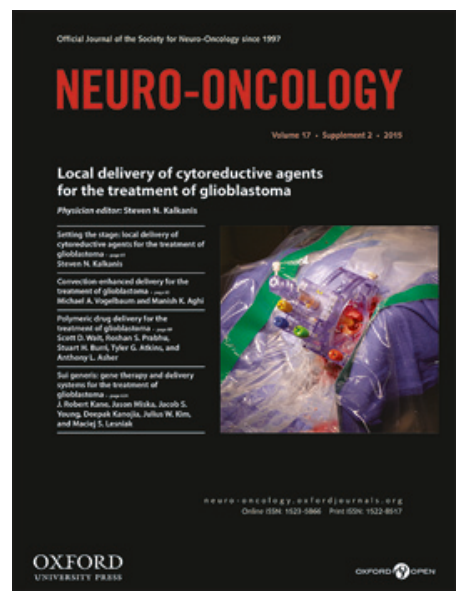

Artikkelen ble e-publisert i tidsskriftet Neuro-Oncology 10.3. 2015 